\title{
Correction to: Prospects of legal regulation in the field of electronic waste management in the context of a circular economy
}

\author{
Gulzhazira llyassova $^{1}$ (D) Aigul Nukusheva ${ }^{1} \cdot$ Leila Arenova $^{2} \cdot$ Guldana Karzhassova $^{3}$. \\ Marzhangul Akimzhanova ${ }^{1}$
}

Published online: 19 November 2020

(c) Springer Nature B.V. 2020

\section{Correction to: Int Environ Agreements https://doi.org/10.1007/s10784-020-09514-3}

In the original publication of the article, the second author's name was published incorrectly. The correct name is given with this Correction.

The original article has been corrected.

Publisher's Note Springer Nature remains neutral with regard to jurisdictional claims in published maps and institutional affiliations.

The original article can be found online at https://doi.org/10.1007/s10784-020-09514-3.

Gulzhazira Ilyassova

ilyassovagu@rambler.ru

1 Department of Civil and Labour Law, Karaganda State University Named After Academician E.A. Buketov, 28 University Str, 100028 Karaganda, Republic of Kazakhstan

2 Department of Criminal Law, Process and Forensics, Karaganda State University Named After Academician E.A. Buketov, 28 University Str, 100028 Karaganda, Republic of Kazakhstan

3 Department of General Legal and Special Disciplines, Karaganda Economic University of Kazpotrebsoyuz, 9 Akademicheskaya Str, 100009 Karaganda, Republic of Kazakhstan 